\title{
Brevibacillus ginsengisoli sp. nov., a denitrifying bacterium isolated from soil of a ginseng field
}

Correspondence
Wan-Taek Im
wandra@kaist.ac.kr

\author{
Sang-Hoon Baek, ${ }^{1}$ Wan-Taek Im, ${ }^{1}$ Hyun Woo Oh, ${ }^{2}$ Jung-Sook Lee, ${ }^{3}$ \\ Hee-Mock $\mathrm{Oh}^{3}$ and Sung-Taik Lee ${ }^{1}$
}

A Gram-positive, rod-shaped, spore-forming bacterium, Gsoil $3088^{\top}$, was isolated from soil from a ginseng field in Pocheon Province in South Korea and characterized in order to determine its taxonomic position. On the basis of $16 \mathrm{~S}$ rRNA gene sequence similarity, strain Gsoil $3088^{\top}$ was shown to belong to the family Paenibacillaceae, being related to Brevibacillus centrosporus (96.6\%), Brevibacillus borstelensis (96.3\%), Brevibacillus parabrevis (96.1\%), Brevibacillus formosus (96.1\%), Brevibacillus brevis (96.1\%) and Brevibacillus laterosporus (96.0\%). The phylogenetic distances from other validly described species within the genus Brevibacillus were greater than $4.0 \%$ (i.e. there was less than $96.0 \%$ similarity). The $\mathrm{G}+\mathrm{C}$ content of the genomic DNA was $52 \cdot 1$ mol\%. Phenotypic and chemotaxonomic data (major menaquinone, MK-7; fatty acid profile, iso- $C_{15: 0}$, iso- $C_{14: 0}$ and anteiso- $C_{15: 0}$ ) supported the affiliation of strain Gsoil $3088^{\top}$ to the genus Brevibacillus. The results of physiological and biochemical tests allowed strain Gsoil $3088^{\top}$ to be distinguished genotypically and phenotypically from Brevibacillus species with validly published names. Strain Gsoil $3088^{\top}$, therefore, represents a novel species of the genus Brevibacillus, for which the name Brevibacillus ginsengisoli sp. nov. is proposed. The type strain is

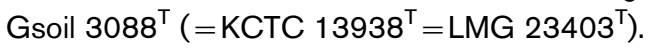

Bacillus brevis was first described in 1900 (Migula, 1900) and was reclassified as a novel species (Brevibacillus brevis) of the novel genus Brevibacillus, along with nine other species of the Bacillus brevis group (Shida et al., 1996). Later, Brevibacillus invocatus (Logan et al., 2002) was isolated from contaminants of an industrial fermentation process and a strain of Brevibacillus brevis was reclassified as a novel Brevibacillus species, Brevibacillus limnophilus (Goto et al., 2004). Recently, Brevibacillus levickii, isolated from the slope of Mount Melbourne, was proposed as a novel species (Allan et al., 2005). Currently, there are 13 Brevibacillus species with validly published names (http://www.bacterio.cict.fr/b/ brevibacillus.html). Members of this genus contain MK-7 as the major respiratory quinone, produce oval endospores in swollen sporangia, possess anteiso- $\mathrm{C}_{15: 0}$ and iso- $\mathrm{C}_{15: 0}$ or

The GenBank/EMBL/DDBJ accession number for the 16S rRNA gene sequence of strain Gsoil $3088^{\top}$ is AB245376.

A transmission electron micrograph of a cell of strain Gsoil $3088^{\top}$ and a table comparing the cellular fatty acid profiles of this strain and members of the genus Brevibacillus are available as supplementary material in IJSEM Online. just iso- $\mathrm{C}_{15: 0}$ as the major cellular fatty acids and have DNA $\mathrm{G}+\mathrm{C}$ contents in the range $42 \cdot 8-57 \cdot 4 \mathrm{~mol} \%$ (Shida et al., 1996).

During a course of study on the culturable aerobic bacterial community of soil from a ginseng field in Pocheon Province, South Korea, a large number of novel bacterial strains were isolated (Im et al., 2005). One of these isolates, strain Gsoil $3088^{\mathrm{T}}$, was subjected to a taxonomic investigation.

In the present study, we conducted a phylogenetic analysis based on 16S rRNA gene sequences, chemotaxonomic characteristics and some important phenotypic characteristics in order to determine the precise taxonomic position of this strain. On the basis of the results obtained in this study, strain Gsoil $3088^{\mathrm{T}}$ is proposed as a novel species of the genus Brevibacillus.

Strain Gsoil $3088^{\mathrm{T}}$ was originally isolated from soil from a ginseng field in Pocheon Province in South Korea. The soil sample was thoroughly suspended in $50 \mathrm{mM}$ phosphate buffer $(\mathrm{pH} \mathrm{7 \cdot 0)}$ and the suspension was spread on one-fifthstrength modified R2A agar plates (containing the following, 
$1^{-1}$ : $0 \cdot 25 \mathrm{~g}$ tryptone, $0 \cdot 25 \mathrm{~g}$ peptone, $0 \cdot 25 \mathrm{~g}$ yeast extract, $0 \cdot 125 \mathrm{~g}$ malt extract, $0 \cdot 125 \mathrm{~g}$ beef extract, $0 \cdot 25 \mathrm{~g}$ Casamino acids, $0.25 \mathrm{~g}$ soytone, $0.5 \mathrm{~g}$ glucose, $0.3 \mathrm{~g}$ soluble starch, $0.2 \mathrm{~g}$ xylan, $0.3 \mathrm{~g} \mathrm{C}_{3} \mathrm{H}_{3} \mathrm{NaO}_{3}, 0.3 \mathrm{~g} \mathrm{~K} \mathrm{~K}_{2} \mathrm{HPO}_{4}, 0.05 \mathrm{~g}$ $\mathrm{MgSO}_{4}, 0 \cdot 05 \mathrm{~g} \mathrm{CaCl}_{2}, 15 \mathrm{~g}$ agar) after being serially diluted with $50 \mathrm{mM}$ phosphate buffer $(\mathrm{pH} 7 \cdot 0)$. The plates were incubated for 1 month at room temperature in an anaerobic chamber (Labplus). The headspace was substituted with a gas mixture comprising $\mathrm{N}_{2} / \mathrm{CO}_{2} / \mathrm{H}_{2}$ (80:15:5, by vol.). Single colonies on the plates were purified by transferring them onto new plates which were incubated using the modified R2A agar or half-strength modified R2A agar under anaerobic conditions. The purified colonies were tentatively identified from partial sequences of the $16 \mathrm{~S}$ rRNA gene (Im et al., 2005). Strain Gsoil $3088^{\mathrm{T}}$ was one of the isolates that appeared on the modified R2A agar plates grown under anaerobic conditions; this strain was routinely cultured on $\mathrm{R} 2 \mathrm{~A}$ agar at $30^{\circ} \mathrm{C}$ and maintained as a glycerol suspension $(20 \%, \mathrm{w} / \mathrm{v})$ at $-70^{\circ} \mathrm{C}$.

A Gram reaction was performed by using the non-staining method as described by Buck (1982). Cell morphology was observed under a Nikon light microscope $(\times 1000)$ and with transmission electron microscopy, using cells grown for 3 days at $30^{\circ} \mathrm{C}$ on $\mathrm{R} 2 \mathrm{~A}$ agar. For the latter, the cells were negatively stained with $1 \%(\mathrm{w} / \mathrm{v})$ phosphotungstic acid and, after air-drying, grids were examined with a transmission electron microscope (model CM-20; Philips). Catalase activity was determined by means of bubble production in $3 \%(\mathrm{v} / \mathrm{v}) \mathrm{H}_{2} \mathrm{O}_{2}$. Oxidase activity was determined using $1 \%(\mathrm{w} / \mathrm{v})$ tetramethyl- $p$-phenylenediamine. For studies on the assimilation of single carbon sources, a defined liquid medium containing a basal salt mixture, comprising $\left(\mathrm{g} \mathrm{l}^{-1}\right)$ $1.8 \mathrm{~g} \mathrm{~K}_{2} \mathrm{HPO}_{4}, 1.08 \mathrm{~g} \mathrm{KH}_{2} \mathrm{PO}_{4}, 0.5 \mathrm{~g} \mathrm{NaNO}_{3}, 0.5 \mathrm{~g} \mathrm{NH}_{4} \mathrm{Cl}$, $0 \cdot 1 \mathrm{~g} \mathrm{KCl}, 0 \cdot 1 \mathrm{~g} \mathrm{MgSO}_{4}$ and $0.05 \mathrm{~g} \mathrm{CaCl}_{2}$. A vitamin solution (Widdel \& Bak, 1992), a trace element solution (SL10; Widdel et al., 1983) and a selenite/tungstate solution (Tschech \& Pfennig, 1984) were added to this medium and the $\mathrm{pH}$ was adjusted to $6 \cdot 8$ by the addition of $1 \cdot 0 \mathrm{M} \mathrm{HCl}$. This liquid medium was poured into 96-well plates and filter-sterilized $25 \times$ carbon sources were added to each well. The plates were incubated at $30{ }^{\circ} \mathrm{C}$ for up to 7 days and growth was examined visually. The negative control well did not contain any carbon source solution and the positive control culture was grown in one well containing R2A broth.

Physiological characteristics were determined by using API $20 \mathrm{E}$ galleries according to the manufacturer's instructions (bioMérieux). Anaerobic growth was tested in serum bottles containing R2A broth supplemented with thioglycolate $\left(1 \mathrm{~g} \mathrm{l}^{-1}\right)$ and in which the headspace was substituted with nitrogen gas. The anaerobic nitrate reduction test to determine the final electron acceptor was tested in serum bottles containing R2A broth supplemented with thioglycolate $\left(1 \mathrm{~g} \mathrm{l}^{-1}\right)$ and in which the headspace was substituted with nitrogen gas; nitrate was added as $\mathrm{KNO}_{3}$ at a concentration of $10 \mathrm{mM}$. Aerobic nitrate reduction was later confirmed by inoculation into $12 \mathrm{ml} \mathrm{R} 2 \mathrm{~A}$ broth supplemented with $10 \mathrm{mM} \mathrm{KNO}_{3}$ in three $25 \mathrm{ml}$ serum bottles. The reduction of nitrate was monitored by using an ion chromatograph (model 790 personal IC; Metrohm) equipped with a conductivity detector and an anion exchange column (Metrosep Anion Supp 4; Metrohm). Tests for the degradation of DNA (DNase agar Scharlau by flooding plates with $1 \mathrm{M} \mathrm{HCl}$ ), casein, chitin, starch (Atlas, 1993), lipid (Kouker \& Jaeger, 1987), xylan and cellulose (Ten et al., 2004) were performed and evaluated after 5 days. Growth at different temperatures $(4,15,25,30,37$ and $\left.42{ }^{\circ} \mathrm{C}\right)$ and various $\mathrm{pH}$ values $(\mathrm{pH} 5 \cdot 0-10 \cdot 0$, using increments of $0.5 \mathrm{pH}$ units) was assessed after 5 days incubation. Salt tolerance was tested on R2A medium supplemented with $1-10 \%(w / v) ~ N a C l$ after 5 days incubation. Growth on nutrient agar, trypticase soy agar and MacConkey agar was also evaluated at $30^{\circ} \mathrm{C}$.

Extraction of genomic DNA was performed with a commercial genomic DNA-extraction kit (Core Biosystem) and PCR-mediated amplification of the $16 \mathrm{~S}$ rRNA gene and sequencing of the purified PCR product were carried out according to Kim et al. (2005). Complete 16S rRNA gene sequences were compiled using SeqMan software (DNASTAR). The 16S rRNA gene sequences of related taxa were obtained from GenBank. Multiple alignments were performed with CLUSTAL_X (Thompson et al., 1997). Gaps were edited using BIOEDIT (Hall, 1999). Evolutionary distances were calculated using the Kimura two-parameter model (Kimura, 1983). A phylogenic tree was constructed by using the neighbour-joining method (Saitou \& Nei, 1987) and maximum-parsimony (Fitch, 1971) using the MEGA3 program (Kumar et al., 2004) with bootstrap values based on 1000 replications (Felsenstein, 1985).

To determine the $\mathrm{G}+\mathrm{C}$ content of chromosomal DNA, genomic DNA of the novel strain was extracted and purified as described by Moore \& Dowhan (1995) and was enzymically degraded into nucleosides. DNA G $+\mathrm{C}$ content was determined as described by Mesbah et al. (1989) using a reverse-phase HPLC. Isoprenoid quinones were extracted with chloroform/methanol $(2: 1, \mathrm{v} / \mathrm{v})$, evaporated under a vacuum and reextracted in $n$-hexane/water $(1: 1, \mathrm{v} / \mathrm{v})$. The crude quinone in the $n$-hexane solution was purified using Sep-Pak cartridges (Waters) and subsequently analysed by HPLC as described previously (Hiraishi et al., 1996). Cellular fatty acids were determined for strains grown on trypticase soy agar (Difco) for 2 days. Cellular fatty acids were saponified, methylated and extracted according to the protocol of the Sherlock Microbial Identification System (MIDI). The fatty acids analysed by GC (6890; Hewlett Packard), were identified by the Microbial Identification software package (Sasser, 1990).

Cells of strain Gsoil $3088^{\mathrm{T}}$ were found to be Gram-positive, aerobic or facultatively anaerobic, motile, rod-shaped and $0 \cdot 3-0.5 \mu \mathrm{m}$ in diameter and $3 \cdot 5-5 \cdot 0 \mu \mathrm{m}$ in length. They possessed peritrichous flagella (see Supplementary Fig. S1 available in IJSEM Online). The novel strain could grow 
anaerobically in the presence of nitrate, but not in the absence of nitrate. Thus the novel strain was able to grow anaerobically using nitrate as a terminal electron acceptor. Colonies grown on R2A agar plates (Difco) for 2 days were smooth, circular, glossy, white and $2-4 \mathrm{~mm}$ in diameter. On R2A agar, strain Gsoil $3088^{\mathrm{T}}$ was able to grow at $20-42^{\circ} \mathrm{C}$, but not at 4 or $45^{\circ} \mathrm{C}$. The physiological characteristics of strain Gsoil $3088^{\mathrm{T}}$ are summarized in the species description and comparisons of selective characteristics with closely related type strains are shown in Table 1.

The 16S rRNA gene sequence of strain Gsoil $3088^{\mathrm{T}}$ determined in this study was 1494 bp in length. Sequence similarity calculations after a simple alignment analysis indicated that the closest relative of strain Gsoil $3088^{\mathrm{T}}$ was Brevibacillus centrosporus $(96 \cdot 6 \%)$. Lower levels of sequence similarity $(<96.5 \%)$ were found with the other recognized Brevibacillus species. The relationship between strain Gsoil $3088^{\mathrm{T}}$ and other members of the genus Brevibacillus was also evident in the phylogenetic tree obtained using the neighbour-joining method (Fig. 1, using 1465 bases). The results obtained showed that strain Gsoil $3088^{\mathrm{T}}$ is closely related to Brevibacillus laterosporus, with which it forms a monophyletic clade with a high bootstrap value.

DNA-DNA hybridization between strain Gsoil $3088^{\mathrm{T}}$ and its nearest phylogenetic neighbours was not attempted since strains differing by $>3.0 \%$ at the $16 \mathrm{~S}$ rRNA gene level are unlikely to exhibit $>70 \%$ similarity at whole-genome level (Stackebrandt \& Goebel, 1994).
The DNA G $+\mathrm{C}$ content of strain Gsoil $3088^{\mathrm{T}}$ was $52 \cdot 1 \mathrm{~mol} \%$. The respiratory quinone system present in strain Gsoil $3088^{\mathrm{T}}$ supports its affiliation to the class Bacilli; indeed, the majority of species in the genus Brevibacillus have MK-7 as the major quinone (Shida et al., 1996). The fatty acid profile of strain Gsoil $3088^{\mathrm{T}}$ (see Supplementary Table S1 available in IJSEM Online) mainly comprised iso$\mathrm{C}_{15: 0}(36 \cdot 3 \%)$, iso- $\mathrm{C}_{14: 0}(15 \cdot 0 \%)$ and anteiso- $\mathrm{C}_{15: 0}$ $(14 \cdot 8 \%)$. These chemotaxonomic data support the affiliation of strain Gsoil $3088^{\mathrm{T}}$ to the genus Brevibacillus.

All of the characteristics determined for strain Gsoil $3088^{\mathrm{T}}$ are in accordance with those for the genus Brevibacillus. However, on the basis of the phylogenetic distance from recognized Brevibacillus species, indicated by relatively low $16 \mathrm{~S}$ rRNA gene sequence similarities $(<97 \%$; see Fig. 1$)$, and the combination of unique phenotypic characteristics (Table 1), it is apparent that strain Gsoil $3088^{\mathrm{T}}$ is not affiliated to any recognized species of the genus Brevibacillus. Therefore, on the basis of the data presented above, strain Gsoil $3088^{\mathrm{T}}$ represents a novel species of the genus Brevibacillus, for which the name Brevibacillus ginsengisoli sp. nov. is proposed.

\section{Description of Brevibacillus ginsengisoli sp. nov.}

Brevibacillus ginsengisoli (gin.sen.gi.so'li. N.L. n. ginsengum ginseng; L. n. solum soil; N.L. gen. n. ginsengisoli of the soil of a ginseng field, the source of the organism).

Table 1. Physiological characteristics of strain Gsoil $3088^{\top}$ and related type strains of Brevibacillus species

Strains: 1, Gsoil $3088^{\mathrm{T}}$ (data from this study); 2, Brevibacillus laterosporus; 3, Brevibacillus borstelensis; 4, Brevibacillus centrosporus; 5, Brevibacillus parabrevis; 6, Brevibacillus formosus; 7, Brevibacillus brevis. Data for reference taxa are from Logan et al. (2002). +, Positive; -, negative; $\mathrm{V}$, variable.

\begin{tabular}{|c|c|c|c|c|c|c|c|}
\hline Characteristic & 1 & 2 & 3 & 4 & 5 & 6 & 7 \\
\hline \multicolumn{8}{|l|}{ Growth temperature $\left({ }^{\circ} \mathrm{C}\right)$ : } \\
\hline Range & $20-42$ & $15-50$ & $20-50$ & $10-40$ & $20-45$ & $20-45$ & $20-45$ \\
\hline Nitrate reduction & + & + & + & $\mathrm{V}$ & + & + & + \\
\hline \multicolumn{8}{|l|}{ Hydrolysis of: } \\
\hline Starch & - & - & - & - & - & - & + \\
\hline \multicolumn{8}{|c|}{ Utilization of sole carbon sources: } \\
\hline L-Alanine & + & + & + & - & + & + & + \\
\hline D-Gluconate & - & - & + & + & + & + & + \\
\hline 2-Ketogluconate & - & $\mathrm{V}$ & - & + & + & + & $\mathrm{V}$ \\
\hline Phenylacetate & - & - & + & - & + & + & + \\
\hline Sucrose & - & - & - & - & + & + & + \\
\hline
\end{tabular}




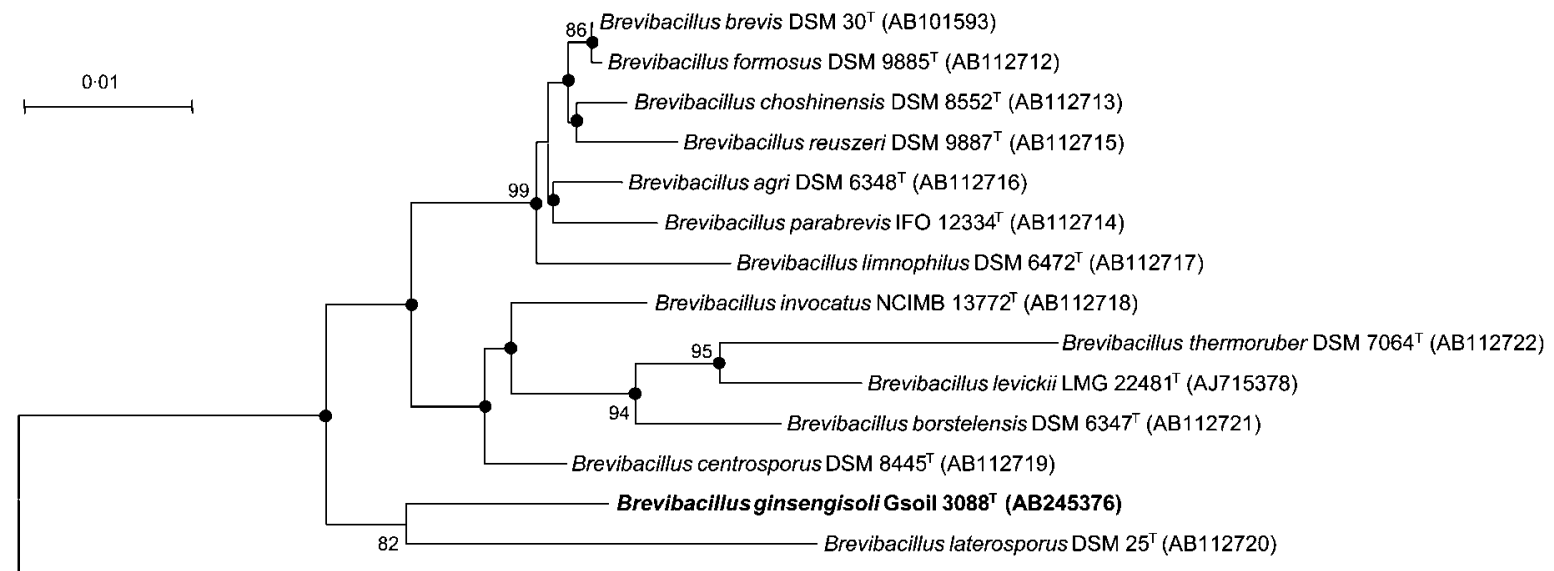

Aneurinibacillus aneurinilyticus DSM $5562^{\top}$ (AB112724)

Fig. 1. Neighbour-joining phylogenetic tree, constructed from a comparative analysis of $16 \mathrm{~S}$ rRNA gene sequences, showing the relationships between strain Gsoil $3088^{\top}$ and related species. Filled circles indicate generic branches that were also recovered by using maximum-parsimony algorithms. Bootstrap values (expressed as percentages of 1000 replications) greater than $65 \%$ are shown at the branch points. Bar, 0.01 substitutions per 1 nucleotide position.

Cells are Gram-positive, aerobic or facultatively anaerobic, motile, slightly curved rods, $0 \cdot 3-0 \cdot 5 \mu \mathrm{m}$ in diameter and $3 \cdot 5-5 \cdot 0 \mu \mathrm{m}$ in length after 2 days culture on R2A agar. Colonies grown on R2A agar for 2 days are smooth, circular, glossy, white and convex. Central and subterminal oval spores are formed in swollen sporangia. Grows well at $20-42{ }^{\circ} \mathrm{C}$ and $\mathrm{pH} 5 \cdot 0-8 \cdot 5$, but does not grow at 4 or $45^{\circ} \mathrm{C}$. Growth occurs in the absence of $\mathrm{NaCl}$ and in the presence of $2.0 \%(\mathrm{w} / \mathrm{v}) \mathrm{NaCl}$, but not $4 \%(\mathrm{w} / \mathrm{v}) \mathrm{NaCl}$. Able to grow anaerobically in denitrifying conditions. Xylan, chitin, starch, cellulose and DNA are not degraded. Substrate utilization, enzyme production, acid production and other physiological characteristics are indicated in Table 1. MK-7 is the predominant respiratory quinone. The major cellular fatty acids are iso- $\mathrm{C}_{15: 0}$, iso- $\mathrm{C}_{14: 0}$ and anteiso- $\mathrm{C}_{15: 0}$ (see Supplementary Table S1). Urease, $\beta$-glucosidase, protease and malic acid assimilation are positive in tests using API 20E and API 20NE strips. Reactions for ONPG hydrolysis, arginine dihydrolase, lysine decarboxylase, ornithine decarboxylase, citrate utilization, hydrogen sulfide production, tryptophan deaminase, idole production, acetoin production and adipic acid assimilation are negative. The following carbon sources are utilized in the API $50 \mathrm{CH}$ and ID 32GN tests: glycerol, D-glucose, salicin, D-celiobiose, sodium acetate, L-serine, valeric acid, L-histidine, 3-hydroxybutyric acid and L-proline. Tests are negative for the utilization of the following substrates: erythritol, D-arabinose, L-arabinose, D-ribose, D-xylose, L-xylose, D-adonitol, methyl- $\beta$-D-xylopyranoside, D-galactose, Dfructose, D-mannose, L-sorbose, L-rhamnose, dulcitol, inositol, D-sorbitol, methyl $\alpha$-D-mannopyranoside, methyl $\alpha$-D-glucopyranoside, amygdalin, arbutin, D-maltose, D-lactose, D-melibiose, D-trehalose, inulin, D-melezitose, D-raffinose, glycogen, xylitol, gentiobiose, D-turanose, Dlyxose, D-tagatose, D-fucose, L-fucose, D-arabitol, L-arabitol, itaconic acid, suberic acid, sodium malonate, 3-hydroxybenzoic acid, propionic acid, capric acid, trisodium citrate and 4-hydroxybenzoic acid. The $\mathrm{G}+\mathrm{C}$ content of the genomic DNA is $52 \cdot 1 \mathrm{~mol} \%$ (as determined by HPLC).

The type strain, Gsoil $3088^{\mathrm{T}}\left(=\mathrm{KCTC} 13938^{\mathrm{T}}=\mathrm{LMG}\right.$ $\left.23403^{\mathrm{T}}\right)$, was isolated from soil from a ginseng field in Pocheon Province, South Korea.

\section{Acknowledgements}

This work was supported by the 21C Frontier Microbial Genomics and Application Center Program, Ministry of Science and Technology (grant MG05-0101-4-0), Republic of Korea.

\section{References}

Allan, R. N., Lebbe, L., Heyrman, J., De Vos, P., Buchanan, C. J. \& Logan, N. A. (2005). Brevibacillus levickii sp. nov. and Aneurinibacillus terranovensis sp. nov., two novel thermoacidophiles isolated from geothermal soils of northern Victoria Land, Antarctica. Int J Syst Evol Microbiol 55, 1039-1050.

Atlas, R. M. (1993). Handbook of Microbiological Media. Edited by L. C. Parks. Boca Raton, FL: CRC Press.

Buck, J. D. (1982). Nonstaining (KOH) method for determination of Gram reactions of marine bacteria. Appl Environ Microbiol 44, 992-993.

Felsenstein, J. (1985). Confidence limits on phylogenies: an approach using the bootstrap. Evolution 39, 783-791.

Fitch, W. M. (1971). Toward defining the course of evolution: minimum change for a specific tree topology. Syst Zool 20, 406-416.

Goto, K., Fujita, R., Kato, Y., Asahara, M. \& Yokota, A. (2004). Reclassification of Brevibacillus brevis strains NCIMB 13288 and DSM 6472 (=NRRL NRS-887) as Aneurinibacillus danicus sp. nov. and Brevibacillus limnophilus sp. nov. Int J Syst Evol Microbiol 54, 419-427. 
Hall, T. A. (1999). BioEdit: a user-friendly biological sequence alignment editor and analysis program for Windows 95/98/NT. Nucleic Acids Symp Ser 41, 95-98.

Hiraishi, A., Ueda, Y., Ishihara, J. \& Mori, T. (1996). Comparative lipoquinone analysis of influent sewage and activated sludge by highperformance liquid chromatography and photodiode array detection. J Gen Appl Microbiol 42, 457-469.

Im, W.-T., Jung, H.-M., Cui, Y.-S., Liu, Q.-M., Zhang, S.-L. \& Lee, S.-T. (2005). Cultivation of the three hundreds of bacterial species from soil of a ginseng field and mining the novel lineage bacteria. In Proceedings of the International Meeting of the Federation of Korean Microbiological Societies, abstract A035, pp. 169. Seoul: Federation of Korean Microbiological Societies.

Kim, M. K., Im, W.-T., Ohta, H., Lee, M. \& Lee, S.-T. (2005). Sphingopyxis granuli sp. nov., a $\beta$-glucosidase-producing bacterium in the family Sphingomonadaceae in the $\alpha-4$ subgroup of the Proteobacteria. J Microbiol 43, 152-157.

Kimura, M. (1983). The Neutral Theory of Molecular Evolution. Cambridge: Cambridge University Press.

Kouker, G. \& Jaeger, K.-E. (1987). Specific and sensitive plate assay for bacterial lipase. Appl Environ Microbiol 53, 211-213.

Kumar, S., Tamura, K. \& Nei, M. (2004). MEGA3: integrated software for molecular evolutionary genetics analysis and sequence alignment. Brief Bioinform 5, 150-163.

Logan, N. A., Forsyth, L., Lebbe, L. \& 8 other authors (2002). Polyphasic identification of Bacillus and Brevibacillus strains from clinical, dairy and industrial specimens and proposal of Brevibacillus invocatus sp. nov. Int J Syst Evol Microbiol 52, 953-966.

Mesbah, M., Premachandran, U. \& Whitman, W. B. (1989). Precise measurement of the $\mathrm{G}+\mathrm{C}$ content of deoxyribonucleic acid by highperformance liquid chromatography. Int J Syst Bacteriol 39, 159-167.

Migula, W. (1900). System der Bakterien, vol. 2. Jena: Gustav Fisher.

Moore, D. D. \& Dowhan, D. (1995). Preparation and analysis of DNA. In Current Protocols in Molecular Biology, pp. 2-11. Edited by
Ausubel, F. M., Brent, R., Kingston, R. E., Moore, D. D., Seidman, J. G., Smith, J. A. \& Struhl, K. New York: Wiley.

Saitou, N. \& Nei, M. (1987). The neighbor-joining method: a new method for reconstructing phylogenetic trees. Mol Biol Evol 4, 406-425.

Sasser, M. (1990). Identification of Bacteria by Gas Chromatography of Cellular Fatty Acids. MIDI Technical Note 101. Newark, DE: MIDI.

Shida, O., Takagi, H., Kadowaki, K. \& Komagata, K. (1996). Proposal for two genera, Brevibacillus gen. nov. and Aneurinibacillus gen. nov. Int J Syst Bacteriol 46, 939-946.

Stackebrandt, E. \& Goebel, B. M. (1994). Taxonomic note: a place for DNA-DNA reassociation and 16S rRNA sequence analysis in the present species definition in bacteriology. Int J Syst Bacteriol 44, 846-849.

Ten, L. N., Im, W.-T., Kim, M.-K., Kang, M.-S. \& Lee, S.-T. (2004). Development of a plate technique for screening of polysaccharidedegrading microorganisms by using a mixture of insoluble chromogenic substrates. J Microbiol Methods 56, 375-382.

Thompson, J. D., Gibson, T. J., Plewniak, F., Jeanmougin, F. \& Higgins, D. G. (1997). The CLUSTAL_X windows interface: flexible strategies for multiple sequence alignment aided by quality analysis tools. Nucleic Acids Res 25, 4876-4882.

Tschech, A. \& Pfennig, N. (1984). Growth yield increase linked to caffeate reduction in Acetobacterium woodii. Arch Microbiol 137, 163-167.

Widdel, F. \& Bak, F. (1992). Gram-negative mesophilic sulphatereducing bacteria. In The Prokaryotes, 2nd edn, pp. 3352-3378. Edited by A. Balows, H. G. Trüper, M. Dworkin, W. Harder \& K. H. Schleifer. New York: Springer.

Widdel, F., Kohring, G. \& Mayer, F. (1983). Studies in dissimilatory sulfate-reducing bacteria that decompose fatty acids. III. Characterization of the filamentous gliding Desulfonema limicola gen. nov., sp. nov. and Desulfonema magnum sp. nov. Arch Microbiol 134, 286-294. 